\title{
Stability of SARS-CoV-2 RNA in Nonsupplemented Saliva
}

\author{
Isabel M. Ott, ${ }^{1}$ Madison S. Strine,${ }^{1}$ Anne E. Watkins, Maikel Boot, Chaney C. Kalinich, \\ Christina A. Harden, Chantal B.F. Vogels, Arnau Casanovas-Massana, Adam J. Moore, \\ M. Catherine Muenker, Maura Nakahata, Maria Tokuyama, Allison Nelson, John Fournier, Santos Bermejo, \\ Melissa Campbell, Rupak Datta, Charles S. Dela Cruz, Shelli F. Farhadian, Albert I. Ko, Akiko Iwasaki, \\ Nathan D. Grubaugh, ${ }^{2}$ Craig B. Wilen, ${ }^{2}$ Anne L. Wyllie,${ }^{2}$ the Yale IMPACT Research team ${ }^{3}$
}

The expense of saliva collection devices designed to stabilize severe acute respiratory syndrome coronavirus 2 RNA is prohibitive to mass testing. However, virus RNA in nonsupplemented saliva is stable for extended periods and at elevated temperatures. Simple plastic tubes for saliva collection will make large-scale testing and continued surveillance easier.

$\mathrm{D}$ espite increased diagnostic testing capacity for severe acute respiratory syndrome coronavirus 2 (SARS-CoV-2), testing in many countries, including the United States, is still inadequate for slowing the coronavirus disease (COVID-19) pandemic. Many persons still do not have access to SARS-CoV-2 testing, and for some that do, an imbalance between supply and demand at large testing centers leads to long delays before results are received. The demand for testing will only increase as many schools, colleges, and workplaces reopen. Ideally, specialized population surveillance-oriented testing would require minimal diversion of resources from clinical diagnostic testing, be affordable and scalable, and enable rapid and reliable virus identification for persons with asymptomatic or subclinical infections. Thus, simplifying the sample collection and testing workflow is critical.

A simple solution is saliva collection. Saliva is a sensitive source for SARS-CoV-2 detection (1-3) and

Author affiliations: Yale School of Public Health, New Haven, Connecticut, USA (I.M. Ott, A.E. Watkins, C.C. Kalinich, C.A. Harden, C.B.F. Vogels, A. Casanovas-Massana, A.J. Moore, M.C. Muenker, M. Nakahata, A.I. Ko, N.D. Grubaugh, A.L. Wyllie); Yale School of Medicine, New Haven (M.S. Strine, M. Boot, M. Tokuyama, A. Nelson, J. Fournier, S. Bermejo, M. Campbell, R. Datta, C.S. Dela Cruz, S.F. Farhadian, A.I. Ko, A. Iwasaki, C. Wilen); Howard Hughes Medical Institute, New Haven (A. Iwasaki)

DOI: https://doi.org/10.3201/eid2704.204199 an alternative sample type for antigen and antibody testing $(4,5)$. In addition, saliva collection is noninvasive, can be reliably performed without trained health professionals, and does not rely on a sometimes-limited swab supply. However, almost all saliva-based tests approved by the US Food and Drug Administration require specialized collection tubes containing stabilization or inactivation buffers that are costly and not always available. Moreover, as saliva continues to gain popularity as a potential specimen to aid testing demands, standardized collection methods have not been defined for saliva collection as they have for swab-based specimen collection. When true saliva is not collected (e.g., if it contains sputum), which can happen with COVID-19 inpatients when saliva is difficult to produce, specimens can be difficult to pipette (6). Combined with untested concerns regarding SARS-CoV-2 RNA stability in saliva, using supplements to reduce degradation and improve sample processing has become common. Previous work with saliva samples, however, has indicated that some buffers optimized for host nucleic acid stabilization may actually inhibit viral RNA detection (7) (S.B. Griesemer et al., unpub. data, https://doi.org/10.1 101/2020.06.16.20133041), particularly in extractionfree PCRs (D.R.E. D.R.E. Ranoa et al., unpub. data, https:/ / doi.org/10.1101/2020.06.18.159434). Thus, if true saliva (relatively easy to pipette) is being tested, the utility of collecting saliva in expensive tubes containing purported stabilization buffers comes into question. To explore the viability of broadly deploying affordable saliva-based surveillance approaches (8), we characterized SARS-CoV-2 RNA stability and virus infectivity in saliva samples stored in widely

\footnotetext{
${ }^{1}$ These first authors contributed equally to this article.

${ }^{2}$ These senior authors contributed equally to this article.

${ }^{3}$ Team members team are listed at the end of this article.
} 
Stability of SARS-CoV-2 RNA in Nonsupplemented Saliva
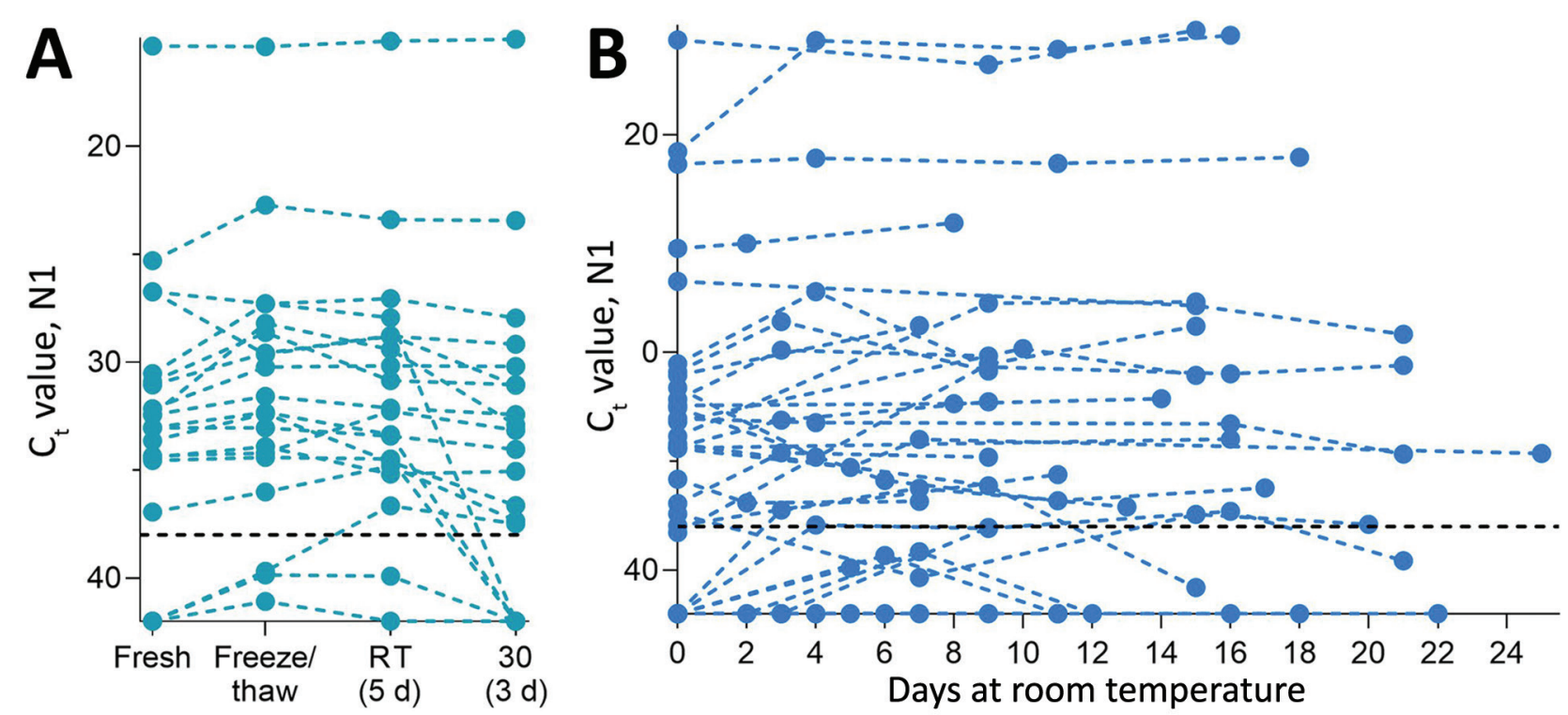

Figure 1. Stability of severe acute respiratory syndrome coronavirus 2 (SARS-CoV-2) RNA (N1) detection in saliva. A) Detection of SARS-CoV-2 RNA in 20 saliva samples on day of sample collection (fresh) did not significantly change after storage at $-80^{\circ} \mathrm{C}$ (to assess the effect of a freeze/thaw cycle), 3 days at $30^{\circ} \mathrm{C}$, or 5 days at RT (recorded as $\approx 19^{\circ} \mathrm{C}$ ). Detection of N1 remained similar to that of freshly collected samples, regardless of starting $C_{t}$ value (Pearson $r=-0.085, p=0.518$ ). B) At $R T$, detection remained stable for up to 25 days. Colored dashed lines track the same sample through different storage conditions. Black horizontal dashed lines represent $\mathrm{C}_{\mathrm{t}}$ 38 , which we applied as the cutoff to determine sample positivity. Samples that remained not detected after 45 cycles are depicted on the $\mathrm{x}$-axis. $\mathrm{C}_{\mathrm{t}}$, cycle threshold; $\mathrm{RT}$, room temperature.

available, sterile, nuclease-free laboratory plastic (polypropylene) tubes.

\section{The Study}

We used saliva collected from COVID-19 inpatients and at-risk healthcare workers into sterile wide-mouth containers (3) without preservatives (nonsupplemented) to evaluate the temporal stability of SARS-CoV-2 RNA at different holding temperatures $\left(-80^{\circ} \mathrm{C}, 4^{\circ} \mathrm{C}\right.$, $\approx 19^{\circ} \mathrm{C}, 30^{\circ} \mathrm{C}$ ) (Appendix, https://wwwnc.cdc.gov/ EID/article/27/4/20-4199-App1.pdf). SARS-CoV-2 RNA from saliva was consistently detected at similar levels regardless of the holding time and temperatures tested. After RNA extraction and quantitative reverse transcription PCR (qRT-PCR) testing for SARS-CoV-2 on the day of saliva collection (3), we aliquoted and stored the remaining 20 sample volumes at $-80^{\circ} \mathrm{C}$, room temperature $\left(\approx 19^{\circ} \mathrm{C}\right)$, and $30^{\circ} \mathrm{C}$. Whether stored at $-80^{\circ} \mathrm{C}$, room temperature ( 5 days), or $30^{\circ} \mathrm{C}$ ( 3 days), the qRT-PCR cycle threshold $\left(C_{t}\right)$ values for the N1 region of the nucleocapsid protein did not differ significantly from those for samples tested on the day of collection (Figure 1, panel A). After the freeze/thaw cycle or storage at room temperature, we observed $C_{t}$ decreases of 1.058 (95\% CI 2.289 to 0.141 ) for freeze/ thaw and 0.960 (95\% CI -2.219 to 0.266$)$ for room temperature; however, the strength of this effect was low. We saw a similar effect after incubation at $30^{\circ} \mathrm{C}$, with a $C_{t}$ increase of 0.973 ( $95 \%$ CI -0.252 to 2.197). Moreover, SARS-CoV-2 RNA remained relatively stable in saliva samples left at room temperature for up to 25 days $\left(C_{t} 0.027,95 \% \mathrm{CI}-0.019\right.$ to $\left.0.071 \mathrm{C}_{t}\right)$ (Figure 1, panel B). Regardless of starting $C_{t}$ value (viral load), this prolonged stability of SARS-CoV-2 RNA was also observed when samples were stored for longer periods at $-80^{\circ} \mathrm{C}$ (maximum 92 days), $4^{\circ} \mathrm{C}$ (maximum 21 days), and $30^{\circ} \mathrm{C}$ (maximum 16 days) (Appendix Figure 1).

Although SARS-CoV-2 RNA from saliva remained stable over time, we observed a decrease in human ribonuclease $\mathrm{P}$ at higher temperatures (room temperature, $\mathrm{C}_{\mathrm{t}} 1.837,95 \%$ CI 0.468 to $3.188 \mathrm{C}_{\mathrm{t}^{\prime}} 30^{\circ} \mathrm{C}$, $C_{t} 3.526,95 \%$ CI 1.750 to $5.349 C_{t^{\prime}}$ Appendix Figure $2)$; the change in concentration was greater than that observed for SARS-CoV-2 RNA (Appendix Figure 3). Thus, although human RNA from saliva degrades without stabilization buffers, SARS-CoV-2 RNA remains protected even at warm temperatures suitable for nuclease activity.

Because saliva has antiviral properties $(9,10)$, we explored the infectiousness of SARS-CoV-2 in saliva samples. We inoculated Vero-E6 cells with 49 saliva samples with higher virus RNA titers $\left(C_{t}\right.$ range $13.57-$ 35.32, median 26.01; Appendix Figure 4) because others have shown that SARS-CoV-2 isolation is uncommon from samples with low virus RNA titers $(11,12$; 


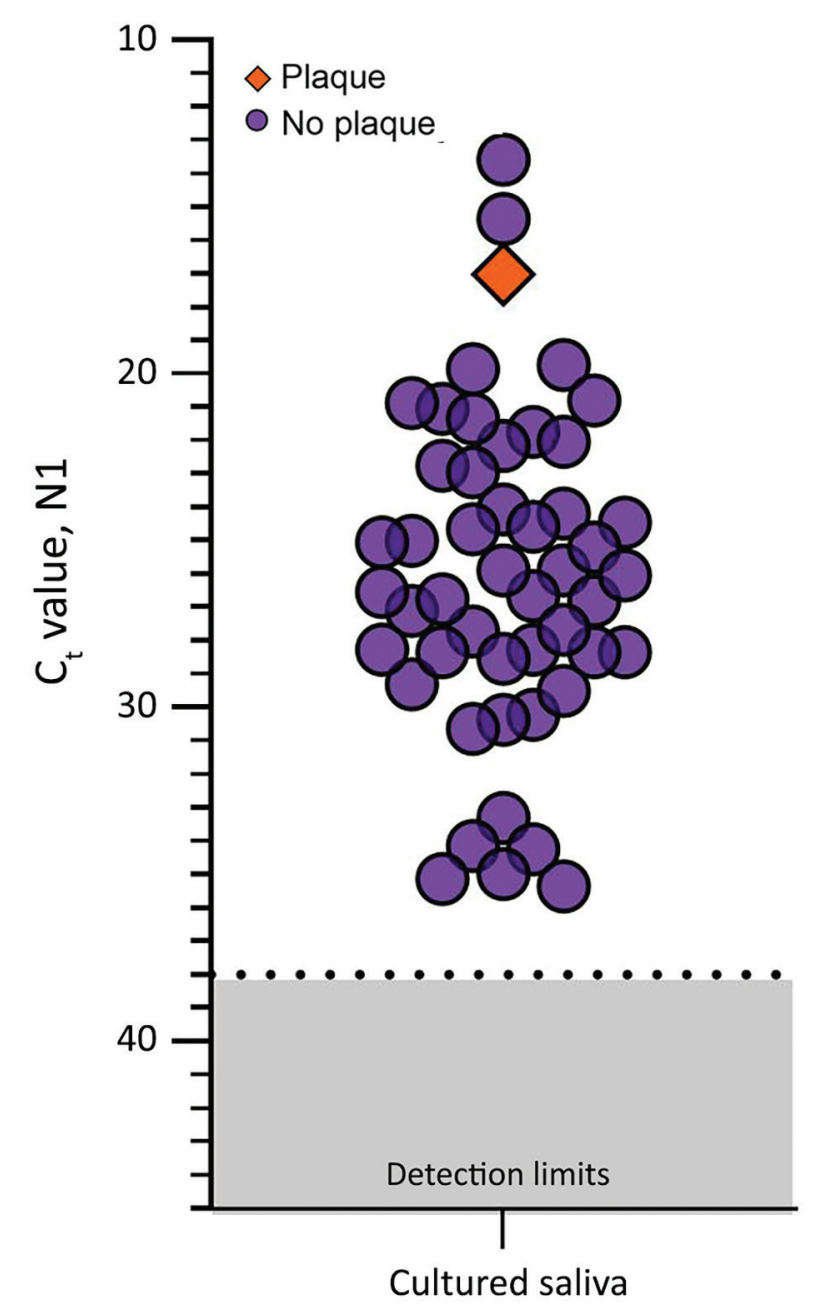

Figure 2. Detection of severe acute respiratory syndrome coronavirus 2 (SARS-CoV-2) in saliva samples tested for infectious SARS-CoV-2. SARS-CoV-2 N1 detection ( $C_{t}$ values) measured by quantitative reverse transcription PCR for each saliva sample incubated with Vero-E6 cells for 72 hours. The orange diamond depicts the only sample that produced plaqueforming units (titer increase of $3.79 \times 10^{4} \mathrm{PFU} / \mathrm{mL}$; purple circles indicate samples that did not produce plaque-forming units by $72 \mathrm{~h}$ after inoculation; dashed lines indicate $C_{t} 38$ (the cutoff for sample positivity); gray shading indicates $\mathrm{C}_{t} \mathrm{~s}$ below the limit of detection. $\mathrm{C}_{\mathrm{t}}$, cycle threshold.

M.D. Folgueira, unpub. data, https:/ / www.medrxiv. org/content/10.1101/2020.06.10.20127837v1). By 72 hours after inoculation, $C_{t}$ values were reduced in 9 $(18.7 \%)$ of the 49 cultured saliva samples tested by qRT-PCR $(-12.90,-11.53,-4.30,-3.68,-3.49,-2.88$, $-2.81,-2.66,-2.40)$. Although these findings suggest an increased number of SARS-CoV-2 RNA copies by 72 hours, they may not definitively demonstrate active virus replication. For instance, $C_{t}$ reductions could also result from sampling artifacts or assay variations (disparities in inoculation, RNA extraction, and qRT-PCR). To determine whether this amplification resulted from detectable, active virus replication, we performed plaque assays in triplicate with cellular lysate from 72 hours after inoculation. Only 1 of these 9 samples produced plaque-forming units; titer increased $3.79 \times 10^{4} \mathrm{PFU} / \mathrm{mL}$ at 1 hour and at 72 hours after inoculation (Figure 2). This finding suggests that increased SARS-CoV-2 genome copies identified by qRT-PCR may fall below the limit of detection in plaque assay sensitivity $(100 \mathrm{PFU} / \mathrm{mL})$ until a certain reduction in $\mathrm{C}_{t}$ is reached (e.g., $\mathrm{C}_{t}$ reduction $\leq 12.90$ ) or that components of saliva possibly inhibit active viral particle production and release in vitro. A similar result has been observed when attempting to perform plaque assays of virus from the colon (13), despite studies showing that SARS-CoV-2 infects gut enterocytes (14).

\section{Conclusions}

The cost of commercial tubes specialized for saliva collection and SARS-CoV-2 RNA stabilization (>\$7/ tube) (Table) can be prohibitive for mass testing. Inexpensive saliva-based testing methods are urgently needed to help reach the capacity required to safely reopen schools and workplaces. We demonstrate the stability of SARS-CoV-2 RNA detection in saliva stored for prolonged periods in a variety of settings, which indicates that saliva can be simply collected without the need for additives.

Previous studies have demonstrated the ease with which saliva can be collected into simple, widemouth containers $(3,15)$ and that buffers marketed for RNA stabilization may be detrimental to SARSCoV-2 detection (S.B. Griesemer et al., unpub data, https://doi.org/10.1101/2020.06.16.20133041). Although some of these buffers are also marketed for virus inactivation, SARS-CoV-2 is still considered a Biosafety Level 2 hazard, meaning that with or without buffer, any saliva sample should still be handled with care. Without the need for RNA stabilization and given the limited evidence of virus replication in saliva samples, affordable alternatives to making testing accessible throughout the country are simple, sterile, nuclease-free plastic containers.

SARS-CoV-2 stability at room temperature and at $30^{\circ} \mathrm{C}$ permits more affordable collection and transport strategies without the need for expensive cooling strategies. Absence of the requirement for cold chain handling also makes saliva testing easier in regions with limited resources. Thus, one key for meeting mass testing demands is collection of saliva in simple, sterile, nuclease-fee tubes, negating the high costs associated with specialized collection devices. 
Table. Possible saliva collection devices for severe acute respiratory virus coronavirus 2 RNA testing

\begin{tabular}{|c|c|c|c|c|}
\hline Tube type & Collection & Buffer type & $\begin{array}{c}\text { Cost per } \\
\text { sample, USD }\end{array}$ & Manufacturer \\
\hline $\begin{array}{l}\text { Oragene•Dx collection } \\
\text { device }(O G D-510)^{*}\end{array}$ & Funnel & $\begin{array}{l}\text { Ethanol }<24 \% \text {; Tris } 1 \%-5 \% \\
\text { (host DNA stabilization) }\end{array}$ & 28.00 & $\begin{array}{c}\text { Genotek, } \\
\text { https://www.dnagenotek.com }\end{array}$ \\
\hline Samplify SD-3000 & Funnel & $\begin{array}{l}\text { Dry preservative; sodium } \\
\text { dodecyl sulfate }<1 \%\end{array}$ & 24.00 & Samplify (URL not available) \\
\hline Saliva collection kit & Funnel & Unknown & 22.47 & $\begin{array}{c}\text { IBI Scientific, } \\
\text { https://www.ibisci.com }\end{array}$ \\
\hline SDNA-1000 small tubes* & $\begin{array}{l}\text { Wide-mouth } \\
\text { tube }\end{array}$ & $\begin{array}{c}\text { Ethanol } 10 \%-25 \% ; \\
\text { Tris } 1 \%-5 \% \text {; thiocyanic } \\
\text { acid:guanidine }(1: 1) \\
25 \%-50 \% ; \text { pH } 7.9-8.3\end{array}$ & 17.99 & $\begin{array}{c}\text { Spectrum Solutions, } \\
\text { https://spectrumsolution.com }\end{array}$ \\
\hline $\begin{array}{l}\text { Saliva RNA Collection and } \\
\text { Preservation Device }\end{array}$ & $\begin{array}{l}\text { Wide-mouth } \\
\text { tube }\end{array}$ & $\begin{array}{l}\text { Unknown liquid, colorless, } \\
\text { odorless }\end{array}$ & 18 & $\begin{array}{c}\text { Norgen (Biotek), } \\
\text { https://norgenbiotek.com }\end{array}$ \\
\hline Liquid biopsy/spit devices & $\begin{array}{l}\text { Complicated unit } \\
\text { (various) }\end{array}$ & Unknown & 9-12 each & $\begin{array}{l}\text { Oasis Diagnostics, } \\
\text { https://4saliva.com }\end{array}$ \\
\hline $\begin{array}{l}\text { OMNIgene·ORAL saliva } \\
\text { collection device }(\mathrm{OM}-505)^{\star}\end{array}$ & Funnel & $\begin{array}{c}\text { Sodium dodecyl sulfate } \\
1 \%-5 \% ; \text { glycine, } \mathrm{N}, \mathrm{N} \text { '-trans- } \\
1,2 \text {-cyclohexanediylbis } \\
\text { [N-(carboxymethyl)-,hydrate } \\
1 \%-5 \% \text {; lithium chloride } \\
0.5 \%-1.5 \%\end{array}$ & 9.50 & Genotek \\
\hline $\begin{array}{l}\text { GeneFix Saliva DNA/RNA } \\
\text { Collection }\end{array}$ & Funnel & Unknown liquid, colorless & 9 & Isohelix, https://isohelix.com \\
\hline $\begin{array}{l}\text { DNA/RNA Shield saliva } \\
\text { collection kit* }\end{array}$ & $\begin{array}{l}\text { Wide-mouth } \\
\text { tube }\end{array}$ & $\begin{array}{l}\text { Unknown liquid, colorless, } \\
\mathrm{pH} 5.0-7\end{array}$ & 7.25 & $\begin{array}{c}\text { Zymo Research, } \\
\text { https://www.zymoresearch.com }\end{array}$ \\
\hline Saliva collection system & Small beaker & Unknown & Unavailable & $\begin{array}{l}\text { Greiner Bio-One, } \\
\text { ttps://www.gbo.com }\end{array}$ \\
\hline $\begin{array}{l}\text { Pedia•SAL Infant/Toddler } \\
\text { Salivary Collection }\end{array}$ & $\begin{array}{l}\text { Soother + } \\
\text { collector }\end{array}$ & None & Unavailable & Oasis Diagnostics \\
\hline Oral swab & Swab & None & 1.76 & $\begin{array}{c}\text { Salimetrics, } \\
\text { https://salimetrics.com }\end{array}$ \\
\hline $\begin{array}{l}\text { Saliva collection aid + } \\
\text { cryovial }\end{array}$ & $\begin{array}{l}\text { Straw }+2 \mathrm{~mL} \\
\text { collection vial }\end{array}$ & None & $\begin{array}{c}1.36 / \text { straw, } \\
0.76 / \text { vial }\end{array}$ & Salimetrics \\
\hline Urine collection cups & Wide-mouth cup & None & 0.47 & $\begin{array}{c}\text { ThermoFisher, } \\
\text { https://www.thermofisher.com }\end{array}$ \\
\hline Sterile tube, large volume & $\begin{array}{l}\text { Wide-mouth } \\
\text { tube }\end{array}$ & None & $\begin{array}{c}0.46(25 \mathrm{~mL}) \\
0.38(5 \mathrm{~mL})\end{array}$ & $\begin{array}{c}\text { Eppendorf, } \\
\text { https://www.eppendorf.com }\end{array}$ \\
\hline Sterile tube, small volume & $\begin{array}{l}\text { Narrow-mouth } \\
\text { tube }\end{array}$ & None & $0.16(2 \mathrm{~mL})$ & ThermoFisher \\
\hline
\end{tabular}

Yale IMPACT Research Team authors (in alphabetical order): Kelly Anastasio, Michael H. Askenase, Maria Batsu, Sean Bickerton, Kristina Brower, Molly L. Bucklin, Staci Cahill, Yiyun Cao, Edward Courchaine, Giuseppe DeIuliis, Rebecca Earnest, Renata Filler, Bertie Geng, Benjamin Goldman-Israelow, Ryan Handoko, William Khoury-Hanold, Daniel Kim, Lynda Knaggs, Maxine Kuang, Eriko Kudo, Sarah Lapidus, Joseph Lim, Melissa Linehan, Peiwen Lu, Alice Lu-Culligan, Amyn A. Malik, Anjelica Martin, Irene Matos, David McDonald, Maksym Minasyan, Nida Naushad, Jessica Nouws, Abeer Obaid, Camila Odio, Ji Eun Oh, Saad Omer, Annsea Park, Hong-Jai Park, Xiaohua Peng, Mary Petrone, Sarah Prophet, Tyler Rice, Kadi-Ann Rose, Lorenzo Sewanan, Lokesh Sharma, Denise Shepard, Mikhail Smolgovsky, Nicole Sonnert, Yvette Strong, Codruta Todeasa, Jordan Valdez, Sofia Velazquez, Arvind Venkataraman, Pavithra Vijayakumar, Elizabeth B. White, Yexin Yang.

\section{Acknowledgments}

We gratefully acknowledge the study participants for their time and commitment to the study. We thank all members of the clinical team at Yale New Haven Hospital for their dedication and work, which made this study possible. We also thank S. Taylor and P. Jack for technical discussions.

This study was supported by the Huffman Family Donor Advised Fund (N.D.G.), Fast Grant funding support from the Emergent Ventures at the Mercatus Center, George Mason University (N.D.G.), the Yale Institute for Global Health (N.D.G.), and the Beatrice Kleinberg Neuwirth Fund (A.I.K.). C.B.F.V. is supported by NWO Rubicon 019.181EN.004.

\section{About the Author}

Ms. Ott is a research assistant in the Department of Epidemiology of Microbial Diseases at the Yale School 
of Public Health, New Haven CT. Her work focuses on developing diagnostic tools for and analyzing functional evolution of viral pathogens, with particular focus on SARS-CoV-2 and endemic arboviruses.

\section{References}

1. Hanson KE, Barker AP, Hillyard DR, Gilmore N, Barrett JW, Orlandi RR, et al. Self-collected anterior nasal and saliva specimens versus health care worker-collected nasopharyngeal swabs for the molecular detection of SARSCoV-2. J Clin Microbiol. 2020;58:e01824-20.

2. Byrne RL, Kay GA, Kontogianni K, Aljayyoussi G, Brown L, Collins AM, et al. Saliva alternative to upper respiratory swabs for SARS-CoV-2 diagnosis. Emerg Infect Dis. 2020;26:2770-1.

3. Wyllie AL, Fournier J, Casanovas-Massana A, Campbell M, Tokuyama M, Vijayakumar P, et al. Saliva or nasopharyngeal swab specimens for detection of SARS-CoV-2. N Engl J Med. 2020;383:1283-6. https://doi.org/10.1056/NEJMc2016359

4. Isho B, Abe KT, Zuo M, Jamal AJ, Rathod B, Wang JH, et al. Persistence of serum and saliva antibody responses to SARS-CoV-2 spike antigens in COVID-19 patients. Sci Immunol. 2020;5:eabe5511.

5. Pisanic N, Randad PR, Kruczynski K, Manabe YC, Thomas DL, Pekosz A, et al. COVID-19 serology at population scale: SARSCoV-2-specific antibody responses in saliva. J Clin Microbiol. 2020;59:e02204-20. https://doi.org/10.1128/JCM.02204-20

6. Landry ML, Criscuolo J, Peaper DR. Challenges in use of saliva for detection of SARS CoV-2 RNA in symptomatic outpatients. J Clin Virol. 2020;130:104567. https:// doi.org/ 10.1016/j.jcv.2020.104567

7. Jones TH, Muehlhauser V. Effect of handling and storage conditions and stabilizing agent on the recovery of viral RNA from oral fluid of pigs. J Virol Methods. 2014;198:26-31. https://doi.org/10.1016/j.jviromet.2013.12.011

8. Vogels CBF, Watkins AE, Harden CA, Brackney DE, Shafer J, Wang J, et al. SalivaDirect: a simplified and flexible platform to enhance SARS-CoV-2 testing capacity. Med. 2020 Dec 26 [Epub ahead of print]. https:/ / doi.org/10.1016/ j.medj.2020.12.010

9. Lieleg O, Lieleg C, Bloom J, Buck CB, Ribbeck K. Mucin biopolymers as broad-spectrum antiviral agents. Biomacromolecules. 2012;13:1724-32. https://doi.org/ $10.1021 / \mathrm{bm} 3001292$

10. Malamud D, Abrams WR, Barber CA, Weissman D, Rehtanz M, Golub E. Antiviral activities in human saliva. Adv Dent Res. 2011;23:34-7. https://doi.org/10.1177/ 0022034511399282

11. Wölfel R, Corman VM, Guggemos W, Seilmaier M, Zange S, Müller MA, et al. Virological assessment of hospitalized patients with COVID-2019. Nature. 2020;581:465-9. https://doi.org/10.1038/s41586-020-2196-x

12. Bullard J, Dust K, Funk D, Strong JE, Alexander D, Garnett L, et al. Predicting infectious SARS-CoV-2 from diagnostic samples. Clin Infect Dis. 2020 May 22 [Epub ahead of print]. https://doi.org/10.1093/cid/ciaa638

13. Zang R, Gomez Castro MF, McCune BT, Zeng Q, Rothlauf PW, Sonnek NM, et al. TMPRSS2 and TMPRSS4 promote SARS-CoV-2 infection of human small intestinal enterocytes. Sci Immunol. 2020;5:eabc3582. https:/ / doi.org/ 10.1126/sciimmunol.abc3582

14. Lamers MM, Beumer J, van der Vaart J, Knoops K, Puschhof J, Breugem TI, et al. SARS-CoV-2 productively infects human gut enterocytes. Science. 2020;369:50-4. https://doi.org/10.1126/science.abc1669

15. Wyllie AL, Chu MLJN, Schellens MHB, van Engelsdorp Gastelaars J, Jansen MD, van der Ende A, et al. Streptococcus pneumoniae in saliva of Dutch primary school children. PLoS One. 2014;9:e102045. https://doi.org/10.1371/ journal.pone.0102045

Address for correspondence: Anne L. Wyllie and Nathan D. Grubaugh, Yale School of Public Health, 60 College St, New Haven, CT 06511, USA; email: anne.wyllie@yale.edu and nathan.grubaugh@yale.edu 